\title{
EFFECT OF SLOW-MOVING LANDSLIDES ON CHURCHES IN THE LIGURIA REGION: A GEOTECHNICAL APPROACH
}

\author{
LUDOVICA CAMBIAGGI ${ }^{1 *}$, CHIARA FERRERO ${ }^{1}$, RICCARDO BERARDI ${ }^{1}$, \\ CHIARA CALDERINI ${ }^{1}$ AND RITA VECCHIATTINI ${ }^{2}$ \\ ${ }^{1}$ Department of Civil, Chemical and Environmental Engineering \\ University of Genoa \\ Via Montallegro 1, 16154 Genoa, Italy \\ email: 1udovica.cambiaggi@edu.unige.it, chiara.ferrero@edu.unige.it, riccardo.berardi@unige.it, \\ chiara.calderini@unige.it (* corresponding author) \\ ${ }^{2}$ Department of Architecture and Design \\ University of Genoa \\ Stradone S. Agostino 37, 16123 Genoa, Italy \\ email: rvecchiattini@unige.it
}

Keywords: Slow-moving landslide, Historic masonry churches, Damage assessment.

\begin{abstract}
Protecting cultural heritage from water-soil interaction related threats is a current issue and the prediction of the effects induced on buildings by landslides is very challenging. The main difficulties lie in the lack of detailed information about landside movements as well as in the modeling of soil-structure interaction. This paper study the effects of a particular category of slow-moving landslides, namely active rotational and translational slides with movement rates of the order of some $\mathrm{mm} / y e a r$, on buildings of historical and cultural interest such as churches. Three case studies located in the Liguria region (Italy) were analyzed by performing FEM and LEM numerical analyses on sections representative of the slope.
\end{abstract}

\section{INTRODUCTION}

Slow-moving landslides may cause different damage to facilities such as break of underground utilities (e.g. water and gas distribution pipelines), interruption of transport infrastructures (e.g. roads and railways) with consequent high cost of maintenances, but also cracking and tilting of buildings. Generally, their occurrence does not cause injuries or fatalities; however, relevant economic losses and damage to both cultural heritage and environmental assets can be recorded.

With respect to cultural heritage, a significant number of sites and remains are not in equilibrium with the environment. Among natural phenomena, earthquakes, flooding and landslides are the main causes of disruption of cultural heritage sites. Although it is difficult to evaluate the percentage of losses caused by each single phenomenon, it can be easily observed that earthquakes and flooding affect a very large area and a significant number of monuments 
at the same time, while landslides act more locally, at the scale of the site, thus making statistical analysis rather complicated. In this respect, it is important to point out that literature is rich of methods for the prediction of seismic damage of several types of structures, while there is a lack of studies dealing with the evaluation of landslide effects on cultural heritage.

This paper investigates the effects of slow-moving landslides on historic masonry churches by means of the analysis of three case studies. Some of the authors carried out an extensive damage survey campaign in 33 listed churches located in the Liguria region (Italy) in areas affected by slow-moving landslides [1]. For each church, detailed information about the crack pattern was obtained by means of on-site inspections [1].

The case studies analyzed in this paper were selected among the buildings investigated in [1]. Firstly, for each church information regarding both the landslide-affected area and the geotechnical soil configuration was collected and analyzed. Landslide type, state of activity and direction were derived from the landslide maps of the basins plans of the Liguria region $[2,3]$ as well as from the Atlante dei Centri Abitati Instabili della Liguria (hereafter called Atlante) [4]. Geotechnical data for each area were also obtained from boreholes, inclinometers, in situ tests and piezometers, when available. Secondly, by means of a GIS software and the acquisition of DTM (Digital Terrain Model) data of the area, it was possible to obtain a sufficiently precise topographic survey, in order to trace representative sections along the slope, particularly along the direction of the landslide. Finally, geotechnical numerical analyses (Finite Element Method - FEM and Limit Equilibrium Method - LEM) were performed with the aim of obtaining horizont respectively. In order to different sets of water the terms of soil displacements, were correlated with the damage in order to evaluate the effects induced by slope movements.

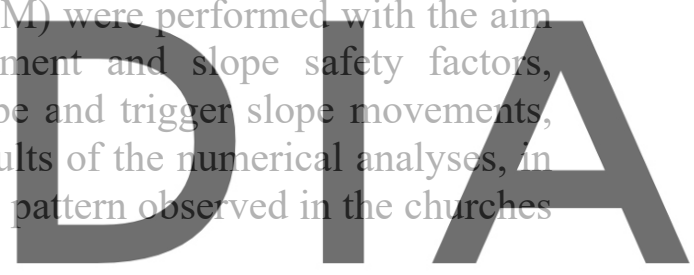

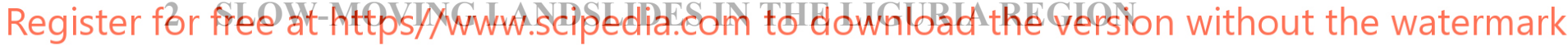

The authors focused their research on Liguria, a region of northern Italy that covers an area of $5418 \mathrm{~km}^{2}$ and is confined within a narrow strip of land bounded to the north by the Aips and Apennines mountain ranges and to the south by the Ligurian sea. Due to its geographical location, orography and morphological and geological setting, Liguria is frequently affected by landslides and floods. It is known that such phenomena are usually triggered by rain infiltration in the soil, leading to an increase in the pore water pressure and therefore in the deterioration of slope stability [5]. In Liguria, this deterioration is facilitated by the presence of numerous rivers that flow into the sea and make the territory very sensitive in rainy periods.

According to the Italian archive of historical information on landslides and floods [6], 1806 landslide events damaged 1233 localities during the period 1800-2001 in the four Provinces of the Liguria Region. The IFFI project (Italian Landslide Inventory), developed by the ISPRA's department for the Geological Survey of Italy and aimed to survey landslides in Italy [7], shows that in the Liguria region 13.475 landslides occurred between 1164 and 2017. In particular, in 2017 an area of $536 \mathrm{~km}^{2}$, equal to $10.1 \%$ of the regional territory, was affected by landslides [8]. 
In a territory with such a high number of landslides, the assessment of the effects of landslides on the regional cultural heritage is a current and social issue to which scientific research must offer a contribution. For the purpose of this work, only landslides characterized by slow movements (i.e. with a speed of the order of some $\mathrm{mm} / \mathrm{year}$ ) were considered.

\section{CASE STUDIES}

This section presents the analysis of the three case studies under consideration: (i) San Nicolò di Capodimonte church in Camogli, (ii) Sant'Olcese church in Sant'Olcese, and (iii) San Carlo church in Cassingheno.

\subsection{San Nicolò di Capodimonte church in Camogli}

\subsubsection{Description of the building and damage survey}

San Nicolò di Capodimonte church (municipality Camogli, province Genoa) is located in a hilly area on the western side of the Promontory of Monte di Portofino (Figure 1a).

The church, whose construction probably dates back to the eleventh century $[9,10]$, is a construction of limited dimensions ( $7 \mathrm{~m}$ wide, $15 \mathrm{~m}$ long) and has a single nave with a transept and three apses (Figure 1b). The nave and the transept are covered by cross vaults, while the apses are covered by semi-circular domes. On the upstream side there is the bell tower, while

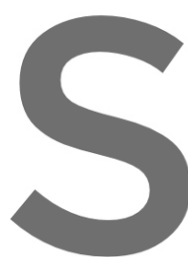
on the sea side, in the trat called "Casa dei Pescat fishermen in the past. external perimeter of th crack gauges, which allow
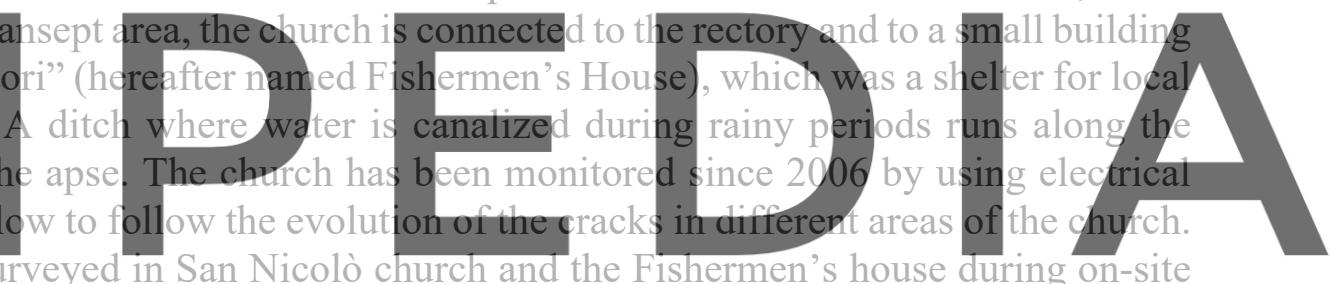

The crack pattern surveyed in San

Register for free at https//WwW.scipedia.com to download the version without the watermark

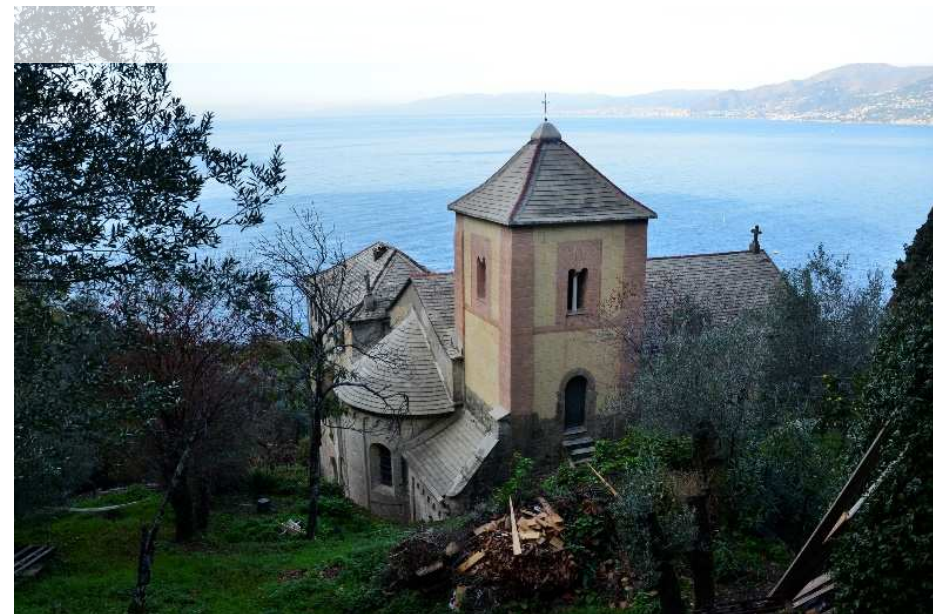

a)

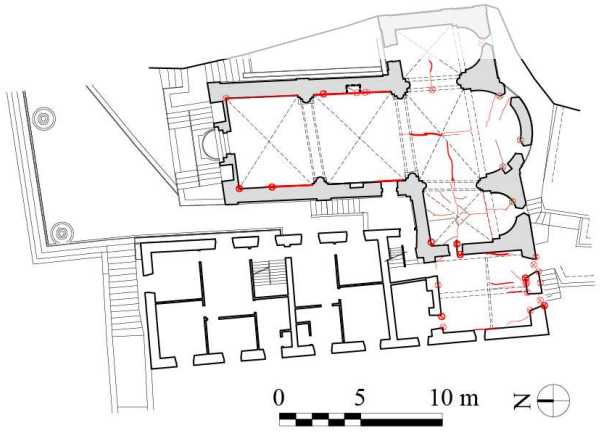

Damage pattern of walls, arches and vaults

Type $\boxminus$ Open crack $\otimes$ Vertical crack in plan

$\square$ Repointed crack $\otimes$ Diagonal crack in plan Width $\boxminus \leq 1 \mathrm{~mm} \boxminus 1-5 \mathrm{~mm} \boxminus \geq 5 \mathrm{~mm}$

b)

Figure 1: San Nicolò di Capodimonte church: a) exterior view, b) damage pattern. 
The church presents slight to moderate damage. Few thin (width up to $1 \mathrm{~mm}$ ) and medium (width between $1 \mathrm{~mm}$ and $5 \mathrm{~mm}$ ) vertical cracks can be observed in the longitudinal walls as well as in apse wall above the windows. The vaults of the transept present cracks oriented parallel and perpendicular to the longitudinal axis of the church. Regarding the Fishermen's house, the authors were given access only to the building portion adjacent to the church. Extensive and severe damage was found in this area. In particular, large (width equal or larger than $5 \mathrm{~mm}$ ) vertical cracks developing from the level of the ground were observed in the external wall continuous with the wall of the church apse.

\subsubsection{Geotechnical analysis and damage assessment}

The area in which the complex is located is limited by two natural streams along which water flows and groundwater is canalized. According to the landslide classification of the Liguria region [2,3], S. Nicolò di Capodimonte church is located in an area not affected by active landslides but characterized by a medium level of landslide susceptibility and high acclivity.

Geological and geotechnical investigations were carried out in 2002, with the aim of defining the stratigraphic sequence of the site, and soil analyses were performed as well. In particular, the results of seven electric tomographic sequences, five refraction seismic tests and four dynamic penetration tests with medium-light penetrometer are available.

A typical sequence of the Ligurian slopes was recognized and assumed: under a superficial heterogeneous clastic blanket, about $3-4 \mathrm{n}$ thick, a $2-3 \mathrm{~m}$ thick laygr of highly
fractured/weathered rock is encountered, the bedrock is a marly limestone belonging to the
formation of the Flysch of Monte Antola.
In winter 2017 a laser scanner survey of both the church and the surrounding area, inclyding
other buildings and the natural slope, was performed through the acquisition of the 3D point
cloud. Through its processing in CAD, it was possible to obtam the plano-altimetric proffle of the area in an accurate way, improving the plano-altimetric profile obtained by processing

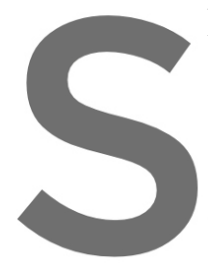

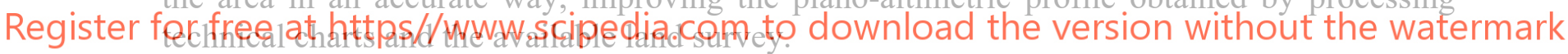

In 2019 the authors took samples of soil in the surroundings of the church in order to perform laboratory tests. The latter allowed to estimate the soil parameters that were used for the Van Genuchten hydraulic model [11] in order to simulate partial saturation condition of soil.

Once the geotechnical and structural data were collected, several FEM analyses were carried out using PLAXIS 2D software. Figure 2 shows the different sections analyzed and the position of the available investigations for section E. The groundwater level was varied in different positions (according to piezometric monitoring) to evaluate its influence on slope stability, under both free-field conditions and introducing the presence of superstructures. In [12], the different soil types were modelled firstly with the elastic-perfectly plastic Mohr-Coulomb model; then, more accurate FEM analyses were performed by adopting the HSM (Hardening Soil Model), a non-linear isotropic hardening model used to better simulate the real behavior of soils [12]. In this paper, the HSM model was further refined using the Van Genuchten model to simulate the variation of the degree of soil saturation due to groundwater level oscillation as well as rain simulation.

Figure 3 shows the trend of vertical and horizontal displacements for section E under the 
Fishermen's House and under the church. It can be noticed that, while vertical displacements exhibit a uniform distribution under the entire complex, horizontal displacements are larger under the Fishermen's House than under the church. These results can explain the crack pattern observed in both buildings. Firstly, the vertical cracks observed in the apse wall as well as in the external wall of the Fishermen's house can be attributed to the occurrence of horizontal displacements. The latter may have caused also the cracks in the vaults oriented parallel to the longitudinal axis of the church (Figure 1b). Secondly, the more severe damage observed in the Fishermen's house can be explained by the larger horizontal displacements obtained under this building. Regarding the cracks in the vaults oriented perpendicular to the longitudinal axis of the church, they may be associated to a local subsidence occurring under the apse of the church. This phenomenon may have been triggered by the significant concentration of rainwater in the area of the apse due to the presence of the ditch mentioned above.

The displacement patterns obtained from numerical analyses were also correlated with the damage levels proposed by [13]. It is important to underline that, while the analyses performed using the HSM model indicated a moderate damage level [12], the more refined analyses carried out with the Van Genuchten model classified the damage as slight, in good agreement with the real damage level of the structure (Figure 4). These results demonstrate that a refined geotechnical modeling, possible only in the presence of soil tests, is necessary in order to predict realistically the damage induced on churches by slow-moving landslides.
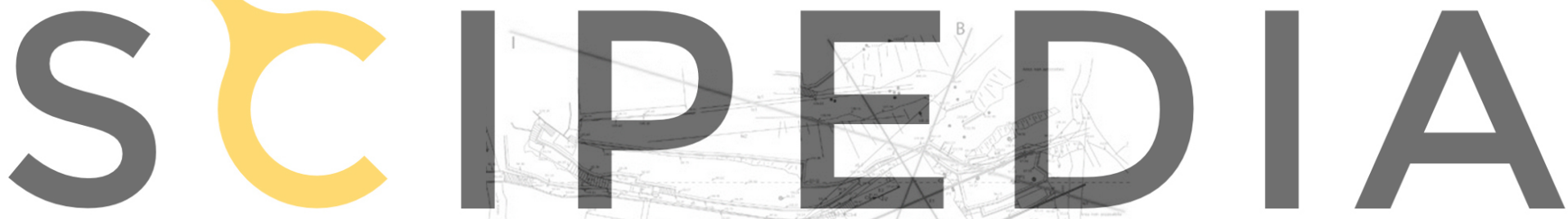

Register for free at https//www.scipedia.com to download the version without the watermark

Fisherman's House

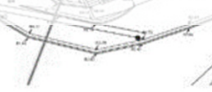

Figure 2: Slope sections analysed.

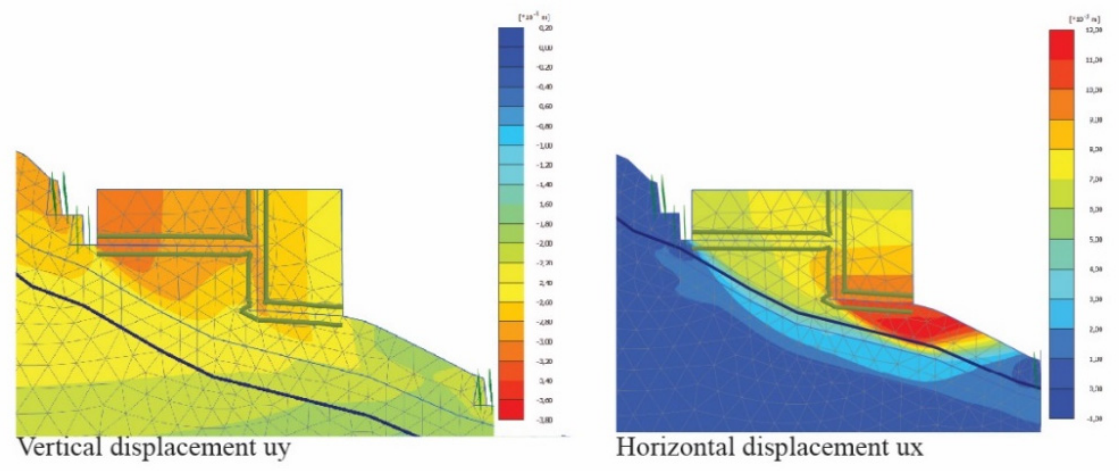

Figure 3: Vertical and horizontal displacements obtained in section E. 


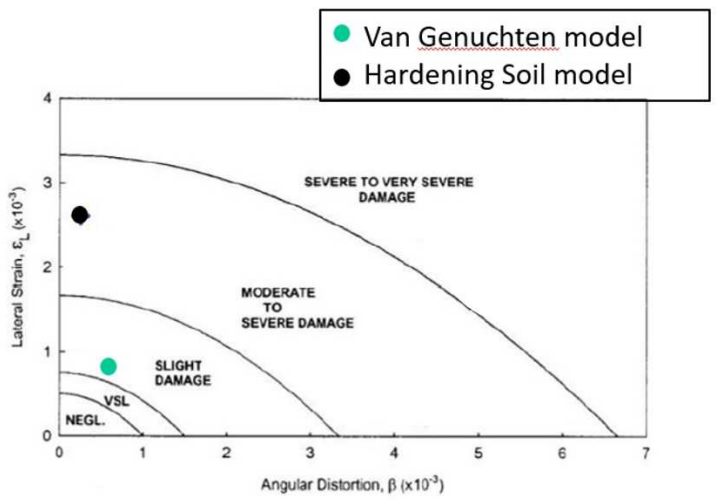

Figure 4: Correlation between angular distorsion and lateral strain (obtained from vertical and horizontal displacement, respectively) and damage level, from [15].

\subsection{Sant' Olcese church in Sant' Olcese}

\subsubsection{Description of the building and damage survey}

Sant'Olcese church is located in the municipality of Sant'Olcese, in the province of Genoa. The church, dating back to the first half of the seventeenth century, has three naves and is about $29 \mathrm{~m}$ long and $14 \mathrm{~m}$ wide (Figuie 5a). The central nave is covered by a barel vault made of brick masonry, while cross vaults are present in the lateral naves. The bex tower, which is now separated from to the church, was rebuilt in the 1930s after the demolition of the original one (adjacent to the church)

The crack pattern observed in Sant'Olcese [1] is reported in Figure 5b.

\section{Register for free at https//www.scipedia.com to download the version without the watermark}

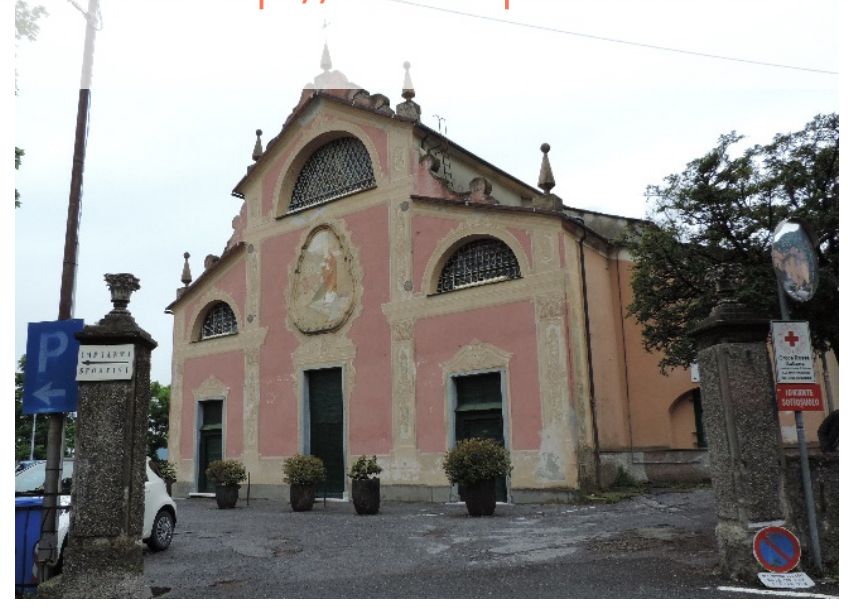

a)

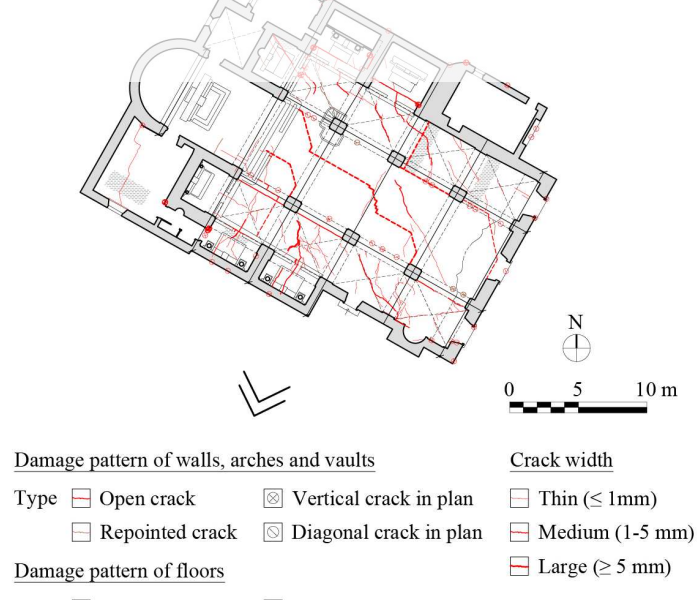
Type $\boxminus$ Crack/gap b)

Figure 5 - Sant'Olcese church: a) exterior view, b) damage pattern (the direction of the landslide acting in the area is indicated with an arrow). 
The church presents extensive and heavy damage, in particular in floors and vaults. Damage in the floor appears in the form of parallel gaps among tiles (ranging from 2 to $5 \mathrm{~mm}$ in width) and localized sinking. Extensive damage can be observed in the vaults with diagonal shear cracks widespread throughout the building. It can be observed that these cracks, which exhibit the same orientation in all the vaults, reflect the gaps observed in the floor, both being oriented almost perpendicular to the landslide direction (indicated with an arrow in Figure 5b). Finally, walls are affected by few minor vertical cracks.

\subsubsection{Geotechnical analysis and damage assessment}

The church is situated on a slope characterized by a slope angle of $15^{\circ}$ (low inclined slope). The area of interest belongs to a large complex active landslide of about $1.09 \mathrm{~km}^{2}$. From Figure 6 , it can be observed that two inclinometers, installed in the framework of the REMOVER monitoring project of the Liguria Region, are present in the landslide area in the slope adjacent to the one where the church is located (Figure 6). They report a horizontal displacement of $175 \mathrm{~mm}$ in 9 years, over $15 \mathrm{~mm} / \mathrm{yr}$. However, no inclinometers can be found on the slope on which the church is situated.

It is important to point out that the area surrounding Sant'Olcese church is not actually well monitored. Only few boreholes, which allowed to define the stratigraphic sequence as well as to model soil stratigraphy, are available in the area uphill of the church. Conversely, no tests for the characteriza

By mean of PLAXI developed. The differe Coulomb constitutive la refined modeling
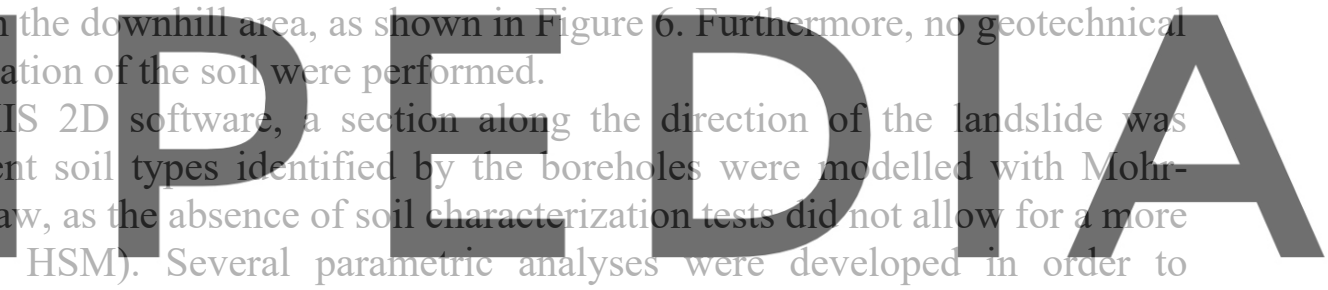

investigate the range of variability of geotechnical parameters. The groundwater level was

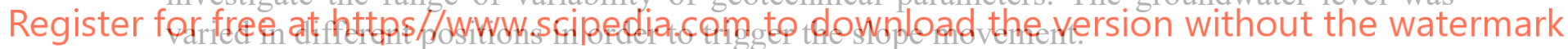

Both horizontal and vertical patterns of displacement were evaluated. The results show only

very small displacements (less than $1 \mathrm{~mm}$ ) in the section under the church while an area of instability downhill of the church was identified (Figure 7). However, the latter is too far away from the building to influence its behavior.

The results of numerical analyses do not appear to be in good agreement with the crack pattern observed in the church. In fact, the heavy damage exhibited by the building as well as the occurrence of parallel cracks in vaults and floors oriented perpendicular to the landslide direction clearly indicates that the church has been subjected to slope movements. The absence of significant soil displacements obtained from numerical analyses can be attributed to the fact that the lack of detailed geotechnical data did not allow for an accurate modeling of the soil. The latter could be achieved by performing new in-situ tests and boreholes, especially in the area downhill of the church, in order to obtain a detailed stratigraphy and fully characterize soil parameters. 


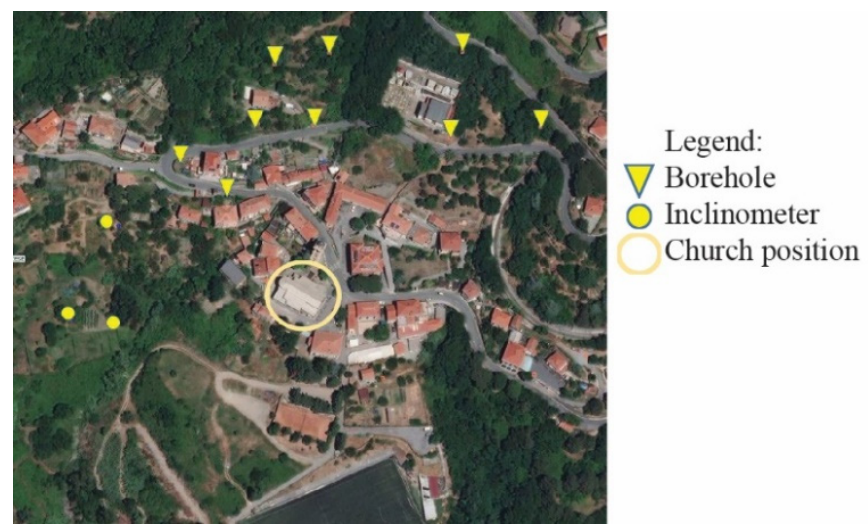

Figure 6: Localization of boreholes and inclinometers in the area of interest.

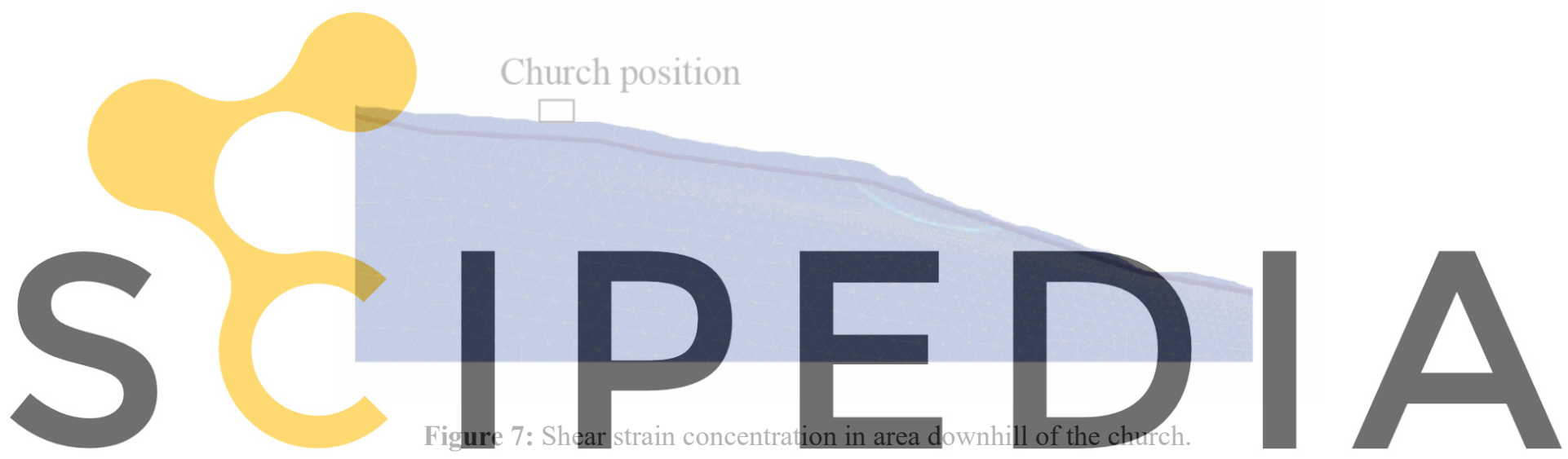

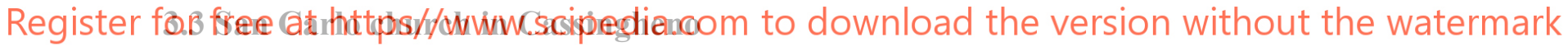

\subsubsection{Description of the building and damage survey}

San Carlo church is located in the village of Cassingheno (municipality Fascia, province of Genoa). Built at the end of the XVI century [14], the church consists of a single nave, a short transept and a semicircular apse. A bell-tower is present on the left side. Considering also the apse, the building is about $20 \mathrm{~m}$ long and $6 \mathrm{~m}$ wide. The nave is covered by a barrel vault made of stone masonry.

Figure $8 \mathrm{a}-\mathrm{b}$ presents the crack pattern of San Carlo church in plan and elevation. The building exhibits extensive and severe cracking as well as large deformations. The floor presents two large parallel gaps (the largest one with a width of $18 \mathrm{~mm}$ ) crossing the entire floor and propagating between longitudinal walls (Figure 8a). These gaps continue up into the walls with a diagonal orientation. Regarding cracking of walls, the most important damage is observed in the second bay behind the façade where series of severe diagonal cracks propagating from the level of the ground and developing upwards towards the apse are observed in both the longitudinal walls (Figure 8b). As for arches and vaults, they exhibit only few and 
slight damage. In particular, a thin longitudinal crack is present in the barrel vault at mid-span. Thanks to the deformation survey performed in [15], the presence of large deformations can be observed (Figure $8 \mathrm{~b}$ ). In particular, a significant rotation of the apse towards the interior of the church can be detected. Furthermore, it can be observed that the left part of the church, where the bell-tower is located, experienced a larger settlement with respect to the right one [15].
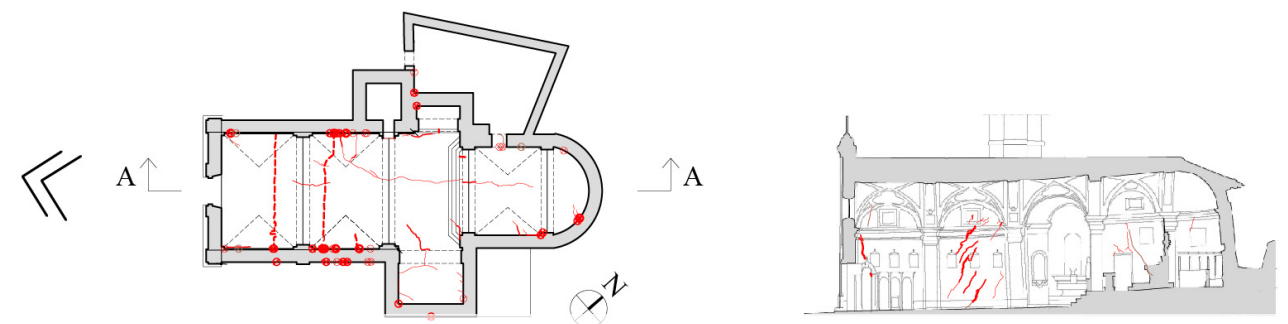

a)

b)
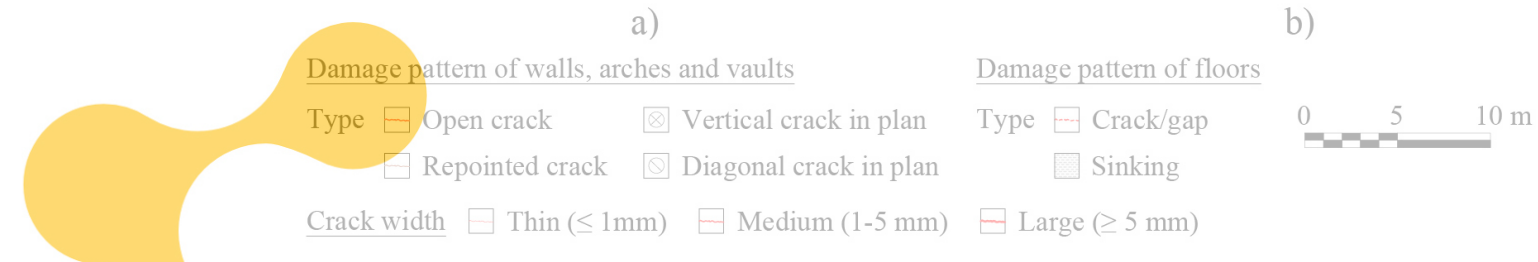

Figure 8: Damage survey of San Carlo church in Cassingheno: a) plan, b) section AA. (The direction of the
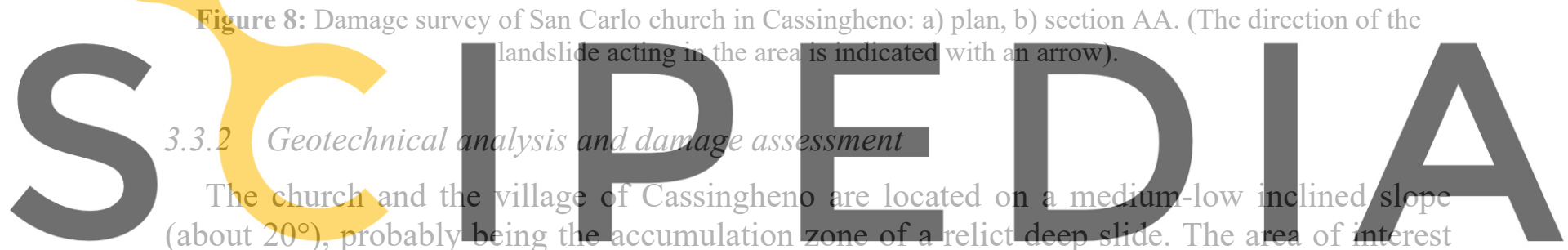

lies on an active landslide of about $1.77 \mathrm{~km}^{2}$ categorized as complex. Thanks to the REMOVER

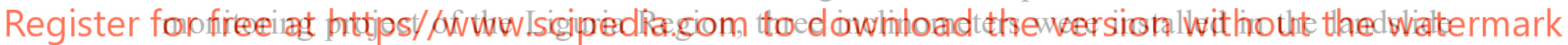
area in order to monitor slope movements. They show small displacements of the blanket at variable depths along the slope; all the instruments indicate a possible failure surface located at depth 9-12 m from ground surface.

Some boreholes performed in previous investigations [16] allowed to define the stratigraphic sequence of the soil, which indicates a thick layer $(10-15 \mathrm{~m})$ of very heterogeneous blanket (sand with clasts, clayey silts) separated from the bedrock (shales) by a transition zone (1-3 m) of weathered rock. The ground water table, whose oscillations follow mainly the seasonality, is located inside the blanket. The results of in-situ tests performed in the past in the area [16] were used to assess geotechnical mechanical properties. These latter were also fully characterized by means of parametric analyses in order to evaluate their range of variability.

Thanks to the GIS software and the acquisition of DTM data of the area, it was possible to obtain a sufficiently precise topographic survey, in order to trace representative sections along the slope, particularly in the direction of the landslide. Figure 9 shows a section of the slope created in SLIDE along the landslide direction. The position of boreholes and inclinometers as well as of the adopted stratigraphic sequence are also indicated.

Both LEM and FEM analyses were performed by some of the authors in [17] in order to 
associate slope displacements with slope safety factors. In the FEM analyses, carried out using PLAXIS 2D, a simple linear elastic perfectly plastic model with Mohr-Coulomb failure criterion was adopted for all the soil layers. In order to reduce the safety factor and trigger slope movements, different sets of water table were considered. Twelve phreatic levels surfaces were modelled, simulating different hydrologic conditions that could actually occur.

The results show that the church is located in an area of potential instability (Figure 10) and is subjected to horizontal and vertical displacements of the same order of magnitude.

Regarding horizontal displacement, a maximum value of about $20 \mathrm{~mm}$ is obtained under the church when analyzing the slope section along landslide direction. This displacement value is in good agreement with the horizontal displacement recorded by the inclinometers and reflects the width of the gaps of the floors. These latter can be, indeed, attributed to the significant horizontal movement experienced by the church in the direction of the landslide. As for vertical displacements, they may explain the rotation of the apse towards the interior of the church.

The presence of severe cracks localized in the second bay of the church as well the settlement experienced by the left part of the church with respect to the right one can be attributed to the occurrence of differential settlement in this area. These displacements could have been responsible for the structural instability of the bell tower, which was strengthened in 1988. It is evident that such local phenomena cannot be captured when modeling the behavior of the entire slope.
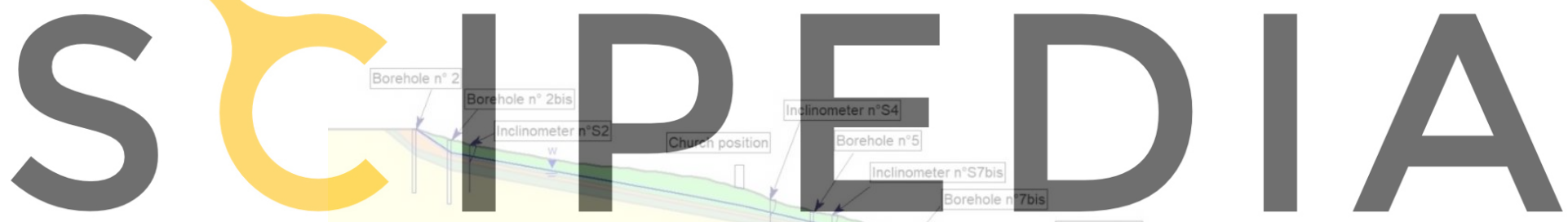

Register for free at https//www.scipedia.com to download the version without the watermark

Figure 9: Boreholes and inclinometers localization along the section analysed.

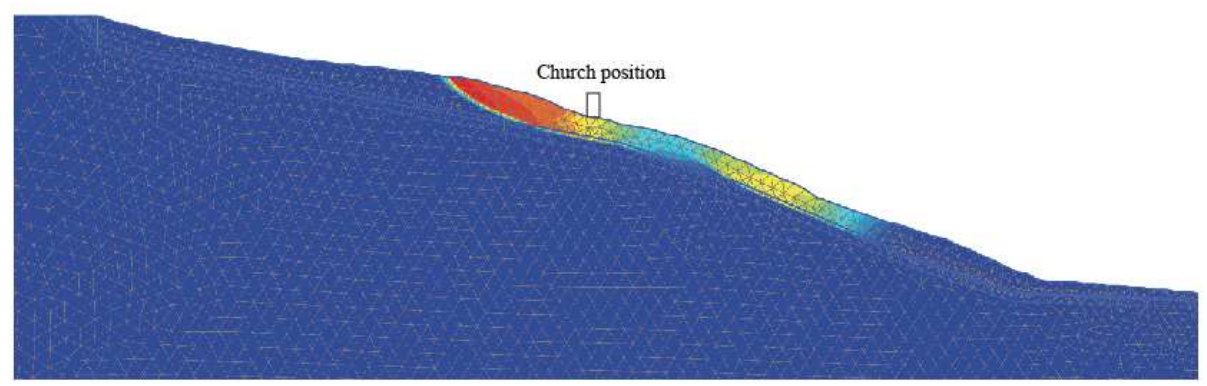

Figure 10: Total displacements $|\mathrm{u}|$. 


\section{CONCLUSION}

This work is part of a research program aimed at protecting cultural heritage from water-soil interaction related threats. In particular, the effects of slope movements on historic masonry churches were investigated by means of the study of three case studies, located in the Liguria region in areas affected by slow-moving landslides. Geotechnical numerical analyses were performed, leading to the following conclusions:

- The main difficulty encountered in the analysis of soil-structure interaction is related to the lack of exhaustive information regarding soil properties, site stratigraphy and landslide movements. In two of the three case studies under consideration, the absence of detailed geotechnical data impeded a refined geotechnical modeling, making it necessary to introduce some simplifications in numerical investigations. Furthermore, several parametric analyses were required for the definition of soil properties and groundwater level. In the case of Sant'Olcese church, the lack of geotechnical data did not allow to develop a numerical model able to catch the ground movements to which the structure was subjected. Conversely, the case of San Nicolò church underlines that a correct prediction of the damage induced by slowmoving landslide is possible only when detailed geotechnical information is available. Indeed, a more refined modeling of the slope, developed thanks to exhaustive geotechnical data as well as in-situ and laboratory test results, allowed to obtain numerical results that are in good agreement with the damage level observed in the structure.

- Geotechnical numerical analysis showed that the identification of the displacement patterns induced by slow-moving landslide is essential to interpret correctly the crack pattern of the church. Indeed, vertical and horizontal soil displacements can be correlated with the damage pattern observed in the churches.

- This work represents a good starting point to draw general conclusions about the structural response of historic masonry churches exposed to slow-moving landslide threats, as the numerical analyses performed so far allowed to associate the damage patterns observed on-site with the displacements induced by landslides.

Acknowledgements. The activity presented in the paper is part of the Research Pro-gram PRIN 2015 "PERICLES - Protecting the Cultural Heritage from water-soil inter-action related threats" - grant n. 2015EAM9S5.

\section{REFERENCES}

[1] Ferrero, C., Cambiaggi, L., Calderini, C., Vecchiattini, R. Damage assessment of historic masonry churches exposed to slow-moving landslides. Submitted in December 2019. International Journal of Architectural Heritage.

[2] Piano di Bacino Stralcio per l'Assetto Idrogeologico, Regione Liguria, 2017. Carte della Suscettività al Dissesto (Landslide Susceptibility Maps). Accessed October 25, 2018. http://www.pianidibacino.ambienteinliguria.it/. 
[3] Piano Stralcio per l'Assetto Idrogeologico, Autorità di bacino distrettuale del fiume Po, 2017. Atlante dei Rischi Idraulici e Idrogeologici (Atlas of Hydraulic and Hydrogeological Risks). Accessed October 25, 2018. http://www.pai.adbpo.it/.

[4] Federici, P.R., M. Capitani, A. Chelli, N. Del Seppia, and A. Serani. Atlante dei Centri Abitati Instabili della Liguria. II. Provincia di Genova (Atlas of the Unstable Inhabited Centres of Liguria. II. Genova province). Regione Liguria. (2004)

[5] Wang G., Sassa, K. Post-failure mobility of saturated sands in undrained load-controlled ring shear tests. Canadian Geotechnical Journal, 39 (2002), pp. 821-837

[6] Guzzetti, F., M. Cardinali, P. Reichenbach, F. Cipolla, C. Sebastiani, M. Galli, and P. Salvati. Landslides triggered by the 23 November 2000 rainfall event in the Imperia Province, Western Liguria, Italy. Engineering Geology (2004) 73 (2): 229-245.

[7] ISPRA: Italian Landslide Inventory Project (IFFI) 2007. Accessed June 26, 2019. http://www.progettoiffi.isprambiente.it

[8] Trigila, A., Iadanza C., Bussettini M., and Lastoria B. Dissesto idrogeologico in Italia: pericolosità e indicatori di rischio. Rapporti 287/2018. Istituto Superiore per la Protezione e la Ricerca Ambientale - ISPRA (in Italian). (2018)

[9] Cavaciocchi,P., Lastrico C., Molinari A., Pesce G., Soppa S. Studi sull'antica Chiesa di San Nicolò di Capodimonte a Camogli. Publication for public use. (2009)

[10] Pesce, G., Cavaciocchi, P., Guastella, R. and Vecchiattini, R. La chiesa di S. Nicolò di Capodimonte (Camogli - GE): dal cantiere di diagnosi al progetto di restauro. In: 7th IGIIC National conference - Lo stato dell'arte 7, 8-10 October 2009, Naples. (2009)

[11] Van Genuchten, M. A closed-form equation for predicting the hydraulic conductivity of unsaturated soils. Soil science society of America journal, 44(5), 892-898. (1980).

[12] Cambiaggi L., Berardi R. Investigation on the damages induced by slope movements on historic buildings: the case of San Nicolò di Capodimonte church in Liguria. XVII European Conference on Soil Mechanics and Geotechnical Engineering ECSMGE, Reykjavik Iceland 2019 ISBN 978-9935-9436-1-3.

[13] Son, M., Cording, E. J., Estimation of building damage due to excavation-induced ground movements. J. Geotech. Geoenviron. Eng., (2005) 131 (2), 162-177

[14] CEI - Chiese e Parrocchie italiane. Chiesa di San Carlo Borromeo (Cassingheno, Fascia).

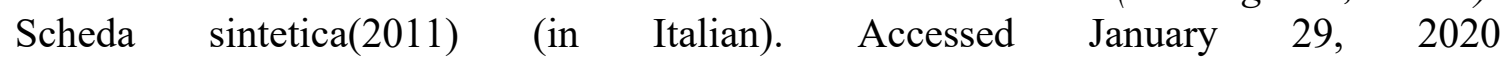
http://www.chieseitaliane.chiesacattolica.it/chieseitaliane

[15] Memme, C. Studio di un borgo ligure in zona di frana attiva: il caso del paese e della chiesa di Cassingheno (Genova). Master thesis, Università degli Studi Genova (2017).

[16] Geoportale Regione Liguria. Visualizzatore Cartografico. Accessed January 20, 2020. https://geoportal.regione.liguria.it

[17] Berardi R., Cambiaggi L. Prediction of slope movement effects on churches for the development of a fragility curve approach. In: Calvetti F., Cotecchia F., Galli A., Jommi C. (eds) Geotechnical Research for Land Protection and Development. CNRIG 2019. Lecture Notes in Civil Engineering, vol 40. Springer, Cham, First Online23 June 2019 (2020) pp. $82-91$. 